\title{
Agronomic features of elephant grass (Pennisetum purpureum $S$ chum) cv. Roxo under irrigation
}

\section{Características agronômicas do capim elefante (Pennisetum purpureum Schum) cv. Roxo sob irrigação}

\author{
Ana Paula da Silva Carvalho ${ }^{1 *}$; Roney Mendes de Arruda $^{2}$; \\ Joadil Gonçalves de Abreu3; Alexandre Lima de Souza ${ }^{4}$; Rosane Cláudia \\ Rodrigues ${ }^{5}$; Leni Rodrigues Lima ${ }^{6}$; Luciano da Silva Cabral ${ }^{3}$; Arthur Behling Neto ${ }^{7}$
}

\begin{abstract}
This study aimed to evaluate how different irrigation water depths influence the agronomical features of elephant grass (Pennisetum purpureum Schum) cv. Roxo. Grass was cultivated in a pasture belonging to the Bovine Sector of the National Agrotechnical School of Caceres - MT. The experiment was a block design with five treatments and four repetitions. Treatments consisted of five water depths: $0=0 \%$ of available water (AW), $1=21 \%$ of AW, $2=34 \%$ of AW, $3=74 \%$ of AW, and $5=100 \%$ of AW. Evaluated features were production (dry matter ha ${ }^{-1}$ ), plant height, leaf/steam ratio, and stem diameter. Dry matter production of cuts from May and July increased linearly with increasing water depth $(\mathrm{P}<0.05)$. Plant height increased linearly as water depth increased in the cuts of May and September, while the height of July cuts was $71.76 \mathrm{~cm}$ under an irrigation depth of $390.77 \mathrm{~mm}$. In May, July, and September cuts, leaf percentage decreased linearly as water depth increased $(\mathrm{P}<0.05)$. An increase of $1 \mathrm{~mm}$ in water depth reduced leaf percentage by $0.0936 \%$ (May), $0.0295 \%$ (July), and $0.0122 \%$ (September). Our results indicate that to improve dry matter production, May, July, and September cuts should be irrigated with water depths of $56.03 \mathrm{~mm}, 601.78 \mathrm{~mm}$, and $577.65 \mathrm{~mm}$, respectively.
\end{abstract}

Key words: Forage growth. Plant height. Productivity.

\section{Resumo}

Objetivou-se com este trabalho avaliar o efeito de diferentes lâminas de irrigação em capim-elefante (Pennisetum purpureum Schum. cv. Roxo) sobre as características agronômicas. O capim foi cultivado em área de capineira da Escola Agrotécnica Federal de Cáceres - MT (EAFC), 16¹3'42" latitude sul e 57 $40^{\prime} 51^{\prime}$ " longitude Oeste de Greenwich. O delineamento experimental foi em blocos casualizados, com quatro repetições. Os tratamentos constaram da aplicação de cinco lâminas de irrigação, lâmina 0: 0\% CC (Capacidade de campo), lâmina 1: 21\% CC, lâmina 2: 34\% CC, lâmina 3: 74\% CC, lâmina 4: $100 \%$ CC de água disponibilizada. Foram avaliadas a produção de matéria seca (MS), altura da planta $(\mathrm{H})$, porcentagem de lâmina foliar (\% LF), relação lâmina foliar:colmo (F:C) e diâmetro do colmo. Nos

\footnotetext{
${ }^{1}$ Discente de Doutorado em Agricultura Tropical, Universidade Federal de Mato Grosso, UFMT, Cuiabá, MT. Brasil. E-mail: anapaulasilvacarvalho@hotmail.com

${ }^{2}$ Prof., Instituto Federal de Educação, Ciência e Tecnologia de Mato Grosso, IFMT, Cáceres, MT, Brasil. E-mail: roney.caceres@ gmail.com

3 Profs., UFMT, Cuiabá, MT, Brasil. E-mail: joadil@terra.com.br, lucianoufmt@gmail.com

4 Prof., UFMT, Rondonópolis, MT, Brasil. E-mail: alexandre@ufmt.br

5 Prof ${ }^{\text {a }}$, Universidade Federal do Maranhão, UFMA, Boa Vista, MA, Brasil. E-mail: claudiarod@gmail.com

6 Discente de Doutorado em Ciência Animal, UFMT, Cuiabá, MT, Brasil. E-mail: leni_rlima@hotmail.com

7 Prof., Universidade Federal de Mato Grosso, UFMT, Sinop, MT, Brasil. E-mail: arthur_behling@hotmail.com

* Author for correspondence
} 
cortes de maio e julho o aumento da água disponibilizada via irrigação promoveu incremento linear (P $<0,05)$ na produção de MS, onde cada $1 \mathrm{~mm}$ de água promoveu incremento de $60,11 \mathrm{~kg} \mathrm{MS} \mathrm{ha}^{-1}$ no mês de maio e 7,43 $\mathrm{kg} \mathrm{MS} \mathrm{ha}^{-1}$ no mês de julho. A (H) aumentou linearmente com o acréscimo de água disponibilizada da irrigação, atingindo a altura máxima de $56,34 \mathrm{~cm}$ com a lâmina d água de $56,03 \mathrm{~mm}$ em maio e $63,89 \mathrm{~cm}$ com a lâmina d'água de $713,11 \mathrm{~mm}$, enquanto no corte de julho a altura foi de $71,76 \mathrm{~cm}$ com a lâmina de irrigação de $390,77 \mathrm{~mm}$. O aumento da quantidade de água disponibilizada promoveu redução linear $(\mathrm{P}<0,05)$ da \% LF no capim-elefante nos cortes de maio, julho e setembro, em que cada 1,0 mm de água de irrigação aplicada reduziu a (\% LF) em 0,0936; 0,0295 e 0,0122\%, respectivamente. Desta forma, do ponto de vista da produção MS ha ${ }^{-1}$, sugere-se para o corte realizado no mês de maio lamina d'água de $56,03 \mathrm{~mm}$, para o corte efetuado em julho lamina d'água de 601,78 mm já para o corte de realizado em setembro a lâmina d’água sugerida é de $577,65 \mathrm{~mm}$.

Palavras-chave: Altura. Capineira. Forragem. Produtividade.

\section{Introduction}

Seasonality in forage production is a major obstacle to the beef and dairy cattle industry because animal maintenance demands stable feed throughout the year. Seasonal fluctuations in feed supply result in the development of livestock seasons and offseasons that limit productivity.

In regions where temperature and light do not limit forage growth, irrigating pasture can reduce the effects of forage scarcity without disposing of the herd (CÓSER et al., 2008). Among the forage species most commonly grown under these conditions, elephant grass (Pennisetum purpureum Schum) stands out due to high yield and cattle preference.

Elephant grass is often supplemented as chopped forage in dairy production, with any rainyseason excess conserved as silage (CARVALHO et al., 1982). The plant originated in Africa and was introduced to Brazil in 1920, becoming widespread and predominantly cultivated in meadows (CARVALHO et al., 1982). Elephant grass is a high-quality, high-production forage species when cultivated under proper management, one that is based on a clear understanding of the morphological, chemical, and digestive changes that occurs throughout its vegetative cycle.

Age influences forage yield and quality; thus, plant age should not exceed 75 days when performing cutting management. During plant development, agronomic traits exhibit the most visible changes, and they are highly correlated with the nutritional and alimentary values of the forage. Of particular importance is vegetation structure, a trait that includes diameter, stem elongation, leaf and stem proportion, plant height, as well as biomass production per unit area. Increases in vegetation structure also factor into important plant characteristics such as dry matter (DM), crude protein (CP), neutral detergent fiber (NDF), and digestion rate $\left(\% \mathrm{~h}^{-1}\right)$ (GOMIDE; QUEIROZ, 1994).

The first experiments examining irrigation of forage species were developed in Piracicaba SP (GUELFI FILHO, 1972; 1978). The results revealed that irrigating elephant grass and guinea grass increased DM yield, but did not eliminate seasonality in forage production. Furthermore, plants were three times more efficient in using water during the summer than the winter.

Elephant grass throughout Brazil has been extensively researched, particularly in the south/ southeast and in the midwestern state of Mato Grosso. However, less attention has been devoted to the effects of irrigation on elephant grass pastures. Thus, this study aimed to evaluate how different irrigation levels affect the agronomic characteristics of elephant grass (P. purpureum cv. Roxo) in Mato Grosso. 


\section{Material and Methods}

The experiment was conducted at the Federal Agrotechnical School of Caceres in southwest Mato Grosso (16 $13^{\prime} 42^{\prime \prime} \mathrm{S}$ and 57 $\left.40^{\prime} 51^{\prime \prime} \mathrm{W}\right), 220$ $\mathrm{km}$ from Cuiaba and at an altitude of $118 \mathrm{~m}$. The climate is Aw (tropical savannas with wet summer and dry winter) following Köppen's classification; the dry season is from May to October and the rainy season is from November to April. Table 1 provides detailed climate data.

The elephant grass had been managed in a 2 ha area for 8 years prior to the experiment, planted with $0.8 \mathrm{~m}$ spacing between furrows. Over the experimental period, a standardization cut was performed (January 2007). Grass was collected in four cuts during March, May, July, and September 2007.

Soil in the area is Red-Yellow Oxisol (EMPAER, 2000), with sandy texture. Soil physicochemical properties at $0-20 \mathrm{~cm}$ depth were as follows: sand,

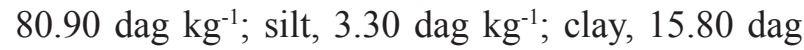
$\mathrm{kg}^{-1}$; $\mathrm{pH}$ in water, 6.6; $\mathrm{pH}$ in $\mathrm{CaCl}_{2}, 5.8 ; \mathrm{P}, 28.5 \mathrm{mg}$ $\mathrm{dm}^{-3}$; K, $15 \mathrm{mg} \mathrm{dm}^{-3}$; Ca, $2.1 \mathrm{cmol}_{\mathrm{c}} \mathrm{dm}^{-3}$; $\mathrm{Mg}, 1.3$ $\mathrm{cmol}_{\mathrm{c}} \mathrm{dm}^{-3} ; \mathrm{Al}, 0 \mathrm{cmol}_{\mathrm{c}} \mathrm{dm}^{-3} ; \mathrm{H}+\mathrm{Al}, 1.1 \mathrm{cmol}_{\mathrm{c}} \mathrm{dm}^{-}$ 3; organic matter, $1.44 \mathrm{dag} \mathrm{kg}^{-1}$; sum of bases, 3.4 $\mathrm{cmol}_{\mathrm{c}} \mathrm{dm}^{-3}$; cation exchange capacity, $4.5 \mathrm{cmol}_{\mathrm{c}} \mathrm{dm}^{-}$ 3; base saturation, $76 \%$.

Based on soil analyses, the following fertilization coverage was implemented: $300 \mathrm{~kg}$ $\mathrm{N}$ ha $^{-1}$ (ammonium sulfate) in six applications, $200 \mathrm{~kg} \mathrm{~K}_{2} \mathrm{O} \mathrm{ha} \mathrm{ha}^{-1}$ (potassium chloride) in four applications, and $30 \mathrm{~kg} \mathrm{P}_{2} \mathrm{O}_{5} \mathrm{ha}^{-1}$ (ammoniated single superphosphate) plus $40 \mathrm{~kg}$ FTE BR 10 $\mathrm{ha}^{-1}$ in a single application after standardization cuts. Fertilizer recommendations and dosage were based on CFSEMG (1999). Soil moisture retention curves were determined at the UFMT Soil Physics Laboratory, using samples collected in August 2006 from undisturbed soil.

Irrigation pipes were distributed along one main line in the corridor between blocks 2 and 4, while sprinklers were set symmetrically in a bifurcation between blocks 1 and 2, equidistant from blocks 3 and 4. Pipes were installed on January 23, 2007, after plots underwent standardization cuts to a height of $10 \mathrm{~cm}$ above ground level. Maintenance fertilization was performed as follows: $250 \mathrm{~kg} \mathrm{ha}^{-1}$ of ammonium sulfate (divided into six applications per 60 days between cuts); $83.33 \mathrm{~kg} \mathrm{ha}^{-1}$ of potassium chloride (divided four applications added simultaneously with nitrogen); $176.47 \mathrm{~kg} \mathrm{ha}^{-1}$ of ammoniated single superphosphate; $40 \mathrm{~kg} \mathrm{ha}^{-1}$ of FTE BR-10.

The plot was irrigated using a $3 \mathrm{CV}$ motor pump set with a 1 inch diameter at the entrance and exit; a welded $25 \mathrm{~mm}$ PVC pipe; two AGROPOLO IS 30 ER sprinklers (nylon spindles) with nozzle nominal diameter $=4.0 \times 3.0 \mathrm{~mm}$ and operating at a pressure of 30 pounds per square inch. Sprinklers were separated by $12 \mathrm{~m}$, had an application intensity of $11.32 \mathrm{~mm} \mathrm{~h}^{-1}$, and a wet diameter of $12 \mathrm{~m}$. Irrigated water collection was quantified using pluviometers made with PET bottles (2 L capacity), centrally installed in the used areas of each plot, $1.50 \mathrm{~m}$ above the soil. Irrigation needs were determined following Rassini (2003), with the EPS (evaporation-plantsoil) use, based on evaporation in the class A tank and precipitation volume.

Irrigation was initiated when the ratio of evaporated to precipitated water volume was $\geq 25$ $\mathrm{mm}$, and continued until depth 4 (L4) reached 100\% of available water (AW), with the remaining depths at $0 \%$ AW (L0), 21\% AW (L1), 34\% AW (L2), and $74 \%$ AW (L3). The field capacity (FC) and permanent wilting point (PWP) were obtained using Richards' extractor, determined with the moisture retention curve (VAN GENUCHTEN, 1980) as cited by (VANZELA; ANDRADE, 2007).

Water depth (WD, mm) differed in each cut depending on percent AW (L0-L4). In cut 1, WD was $1.22,13.74,26.88,45.12$, and 56.03 ; in cut 2 , WD was 6.4, 48.01, 101.01, 304.94, and 601.78; finally in cut 3 , WD was $4.57,127.82,234.92$, 497.15, and 713.11. 
The experiment was a randomized block design with five treatments (depths) and four replications. Each plot comprised four rows of elephant grass spaced $0.80 \mathrm{~m}$ with $5 \mathrm{~m}$ length, yielding $16 \mathrm{~m}^{2}$ in total. The used area was $6.4 \mathrm{~m}^{2}$ and included the two central rows, discounting $0.50 \mathrm{~m}$ at the edges.

Evaluated agronomic characteristics were plant height (cm, from soil surface up to height of the last exposed ligule), leaf blade percentage (leaf blade weight in relation to stem + leaf blade weight), and dry matter production ( $\mathrm{t} \mathrm{ha} \mathrm{a}^{-1}$, dry mass cut close to the soil within the used area).

Standardization cuts to $10 \mathrm{~cm}$ above ground level were performed using a machete on January 23, 2007. Other cuts to the same height were performed every 60 days throughout March, May, July, and September 2007.

Forage production per plot was obtained from near-surface cuts of all plants in the used area $\left(6.4 \mathrm{~m}^{2}\right)$. Samples were weighed in the field, on a scale with $100 \mathrm{~g}$ precision. Two representative subsamples per plot were removed. A 10 tiller subsample was used to evaluate DM content, while another five-tiller sub-sample was used to determine agronomic characteristics (height, stem diameter, leaf blade percentage, and leaf/stem ratio).

Samples were ground in the Cattle Sector of the EAFC, using a Wiley mill with a $1 \mathrm{~mm}$ mesh sieve. Definitive $\mathrm{DM}$ at $105^{\circ} \mathrm{C}$ was determined at the EAFC Microbiology Laboratory.

Data were subjected to ANOVA and regression in SAEG (1998), under the following statistical model:

$$
Y_{i j k}=m+T_{i}+B_{j}+e_{i j k} \text {, }
$$

where

$\mathrm{Y}_{\mathrm{ijk}}=$ value of kth plot under ith irrigation depth in the jth block;

$\mathrm{m}=$ general constant;

$\mathrm{T}_{\mathrm{i}}=$ effect of ith irrigation depth;

$B_{j}=$ effect of $j$ th block;

$\mathrm{e}_{\mathrm{ijk}}=$ random error of each observation.

\section{Results and Discussion}

March climatic conditions did not require irrigation (Table 1) and therefore the regression did not account for water depth. On average, sampled elephant grass during this period had the following characteristics: $6598.76 \mathrm{~kg} \mathrm{DM} \mathrm{ha}{ }^{-1}$, $72.41 \mathrm{~cm}$ height, $15.34 \mathrm{~mm}$ stem diameter, $49.72 \%$ leaf blade proportion, and 1.00 leaf/stem ratio. In May and July, irrigated water and DM production were linearly related $(\mathrm{P}<0.05)$; DM production increased by 60.11 (May) and $7.43 \mathrm{~kg} \mathrm{ha}^{-1}$ (July) with every $1.0 \mathrm{~mm}$ water applied (Figures $1 \mathrm{a}$ and 1b). Our results corroborated previous findings on irrigated elephant grass (TEIXEIRA et al., 2009). We also noted that irrigation water use was more efficient in May, probably because temperature, humidity, and solar radiation were all lower than in July. However, the minimum average temperature $\left(20.4^{\circ} \mathrm{C}\right)$ was still well above the lower basal temperature $\left(13.9^{\circ} \mathrm{C}\right)$ tolerated by elephant grass. Furthermore, soil water content was low in May, given that there was $132.1 \mathrm{~mm}$ of evaporation but only $33.2 \mathrm{~mm}$ of rainfall. 
Table 1. Mean values of relative humidity $(\mathrm{RH} ; \%)$, maximum/minimum temperatures $\left({ }^{\circ} \mathrm{C}\right)$, rainfall $(\mathrm{mm})$, and evaporation $(\mathrm{mm})$ during the experiment.

\begin{tabular}{lccccc}
\hline Period & RH & $\begin{array}{c}\text { Maximum } \\
\text { temperature }\end{array}$ & $\begin{array}{c}\text { Minimum } \\
\text { temperature }\end{array}$ & Rainfall & Evaporation \\
\hline January & 82.00 & 34.0 & 24.0 & 458.1 & 80.0 \\
February & 81.00 & 32.5 & 23.5 & 913.0 & 40.0 \\
March & 78.00 & 33.4 & 23.4 & 171.5 & 99.2 \\
April & 77.00 & 34.4 & 22.5 & 18.0 & 81.8 \\
May & 73.00 & 31.0 & 18.2 & 33.2 & 132.1 \\
June & 66.00 & 32.2 & 17.1 & 0.0 & 29.5 \\
July & 68.00 & 31.2 & 16.5 & 62.3 & 97.3 \\
August & 58.00 & 32.8 & 15.7 & 0.0 & 140.2 \\
September & 62.00 & 35.9 & 22.0 & 9.5 & 117.9 \\
October & 72.00 & 35.2 & 22.9 & 142.0 & 120.4 \\
November & 81.50 & 33.0 & 21.3 & 147.8 & 105.3 \\
December & 80.00 & 33.5 & 21.8 & 146.7 & 92.8 \\
\hline Grand mean & 73.21 & 33.3 & 20.7 & 175.1 & 94.7 \\
\hline
\end{tabular}

Data from the Agro-climatic Station $83405 / 9^{\circ}$ Distrito INMET/ EAFCáceres.

September cuts were of plants that grew during winter. Irrigation water levels exerted a quadratic effect $(\mathrm{P}<0.05)$ on $\mathrm{DM}$ production, which reached a maximum of $3,500 \mathrm{~kg} \mathrm{ha}^{-1}$ at a water depth of $577.65 \mathrm{~mm}$ (Figure 1). Similarly, a previous study on Napier grass and mombaça guinea grass found that irrigation resulted in higher DM yield than no irrigation (RIBEIRO et al., 2009).

Our data suggests that soil moisture is a limiting factor in elephant grass cv. Roxo production. May, July, and September cuts (without irrigation) had lower DM production than March and November cuts, periods that coincided with the end and beginning of the rainy season, respectively. A previous study obtained 9,200 $\mathrm{kg} \mathrm{DM} \mathrm{ha-1} \mathrm{of}$ elephant grass cv. Napier after regrowth for 56 days during spring (LIMA et al., 2007), lower than values found in the present work. When comparing the effect of irrigation water depth on DM production in dry periods (May, July, September), we observed that increased depth caused DM to rise by $193.61 \%$,
$519.81 \%, 375.20 \%$, respectively, from DM at lower depth. Dry matter production observed in November cuts at L0 did not change as dramatically compared with L4 treatments. However, this relatively smaller difference probably resulted from nutrients accumulated during dry-period fertilization, which subsequently solubilized in rainwater.

May and September cuts exhibited a linear relationship between plant height and irrigation water levels ( $\mathrm{P}<0.05$; Figure $2 \mathrm{a}$ and $2 \mathrm{c})$; height increased by 0.3725 (May) and $0.0682 \mathrm{~cm}$ (September) for every $1.0 \mathrm{~mm}$ of water. In July, plant height and irrigation water had a quadratic relationship ( $\mathrm{P}<0.05)$, with a maximum height of $71.76 \mathrm{~cm}$ at a water level of $390.77 \mathrm{~mm}$ (Figure 2b).

Plant height and DM production were positively correlated (Figure 3), suggesting that the former can act as a proxy for the latter when evaluating elephant grass cv. Roxo productivity. 
Figure 1. Estimated dry matter $(\mathrm{DM})$ production $(\mathrm{kg} / \mathrm{ha})$ in elephant grass $\mathrm{cv}$. Roxo as a function of water applied (mm) during irrigation. (a) May, (b) July, (c) September.

(a)

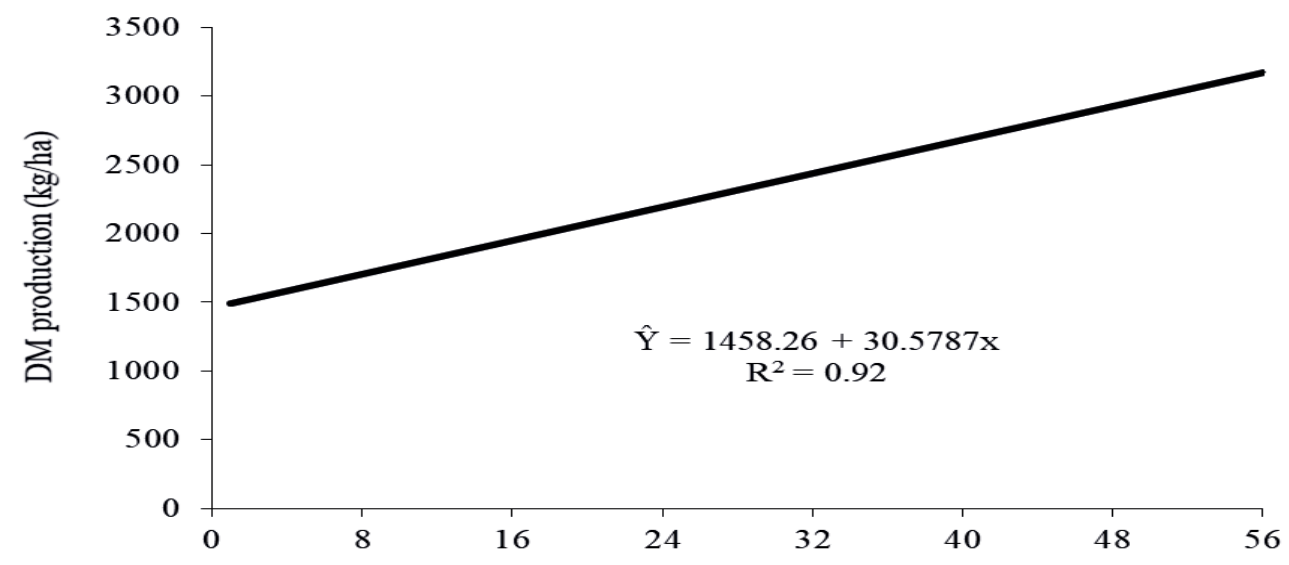

Amount of water applied (mm)

(b)

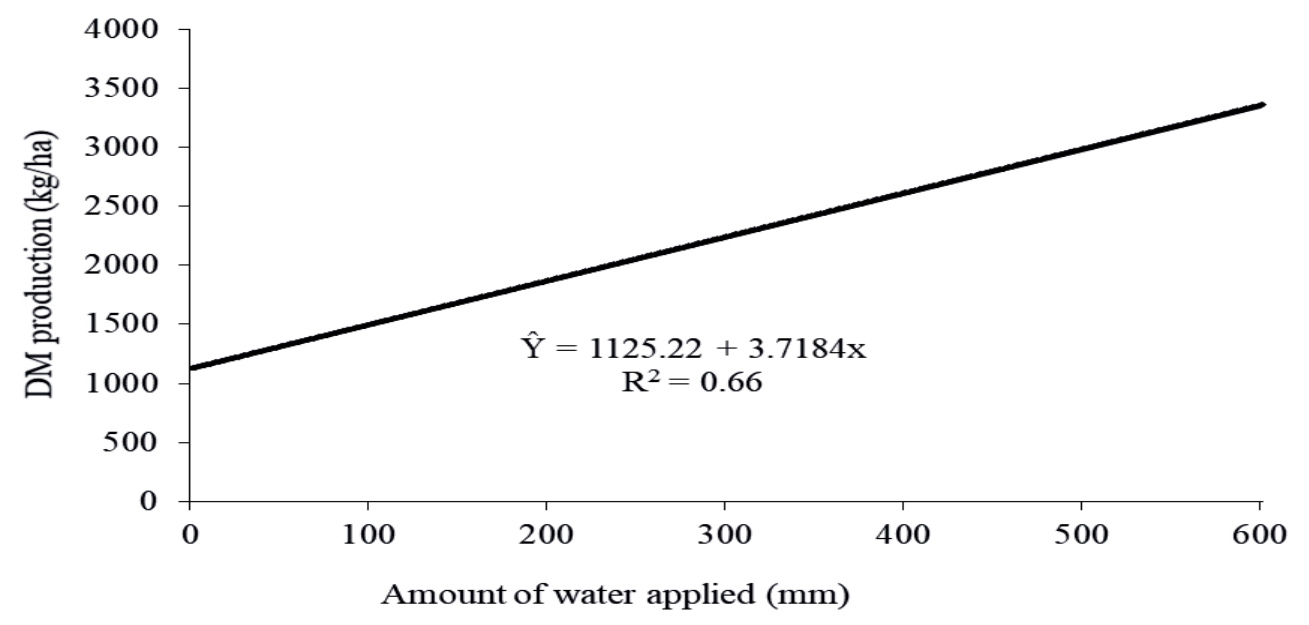

(c)

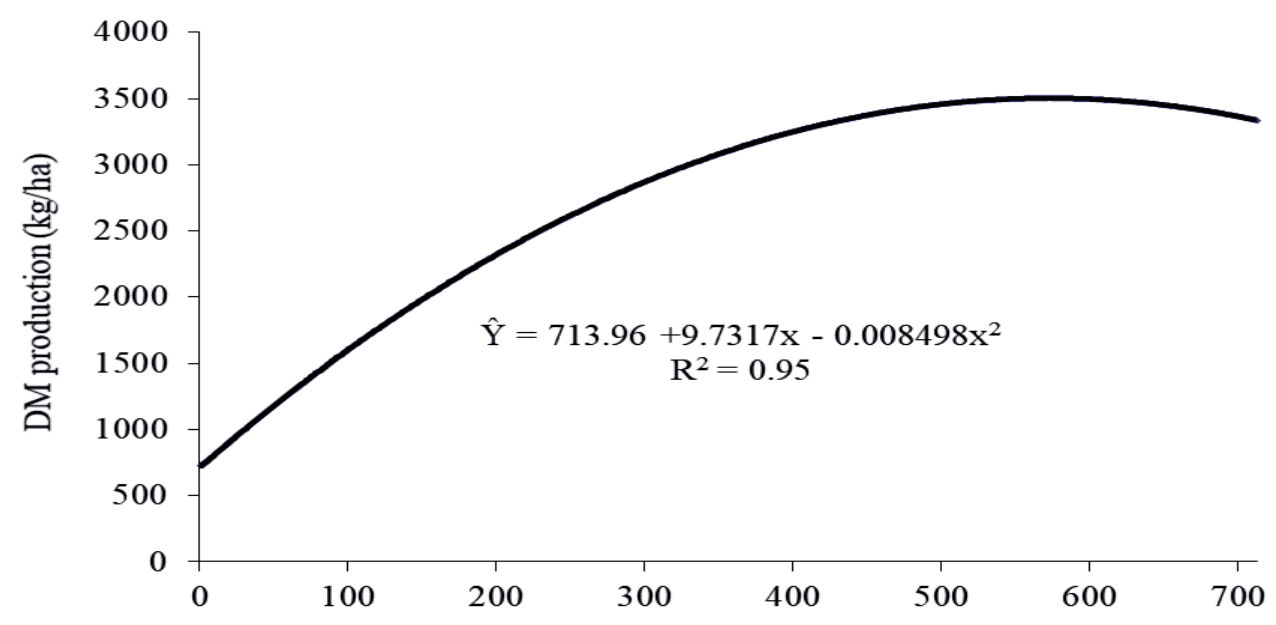

Amount of water applied (mm) 
Figure 2. Estimated height $(\mathrm{cm})$ of elephant grass $\mathrm{cv}$. Roxo as a function of water applied $(\mathrm{mm})$ during irrigation. (a) May, (b) July, (c) September.

(a)

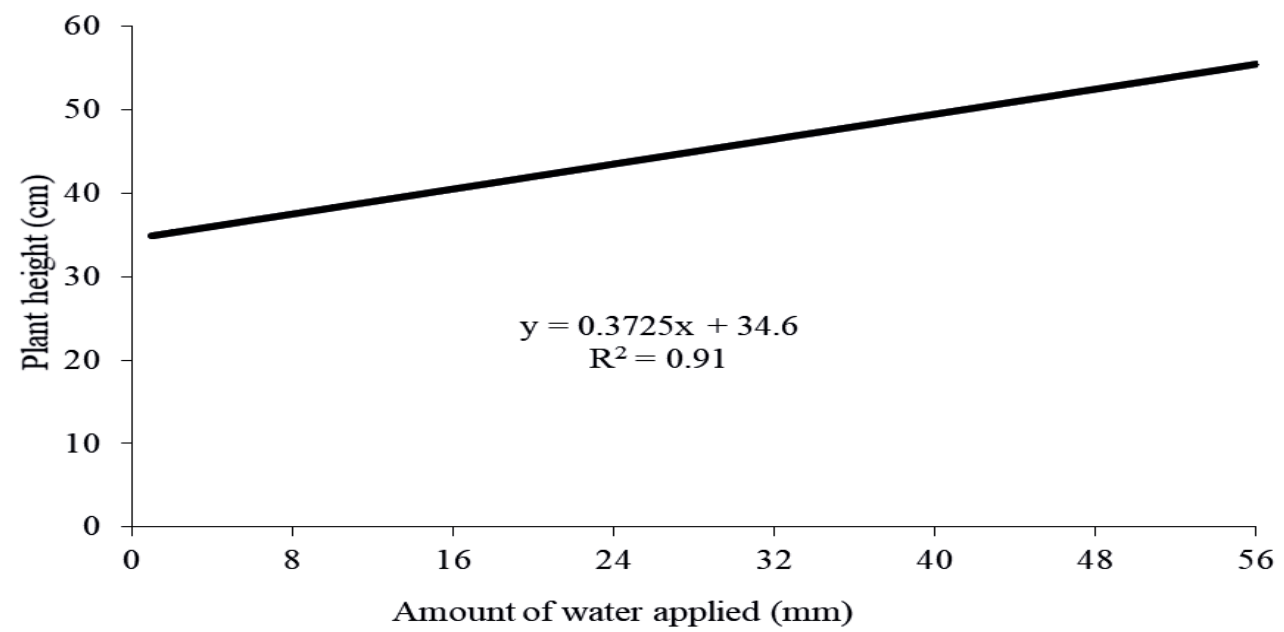

(b)

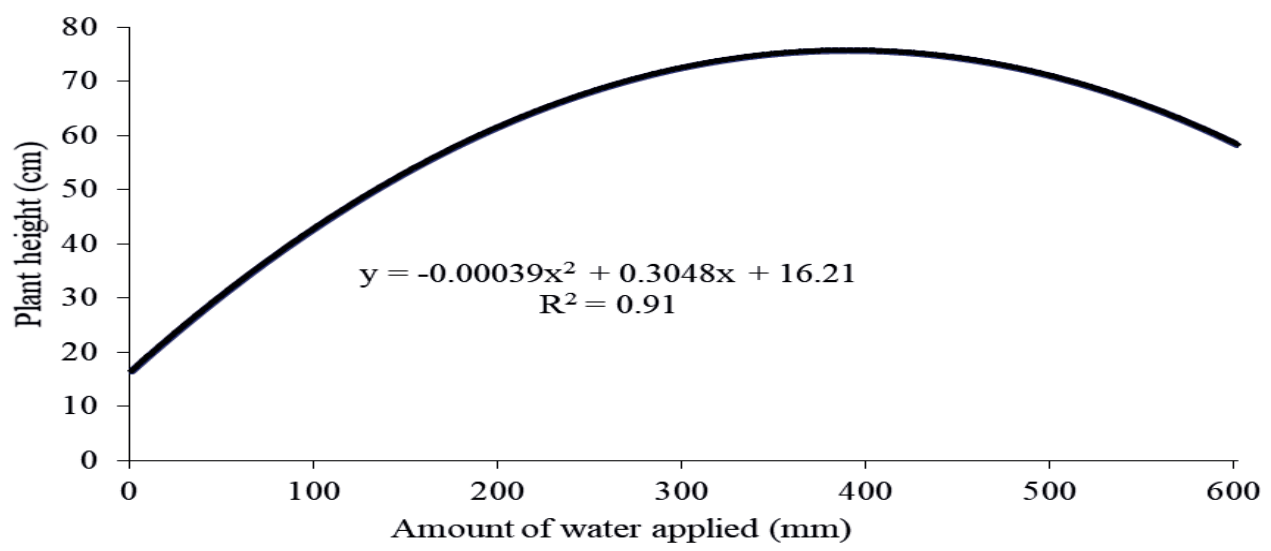

(c)

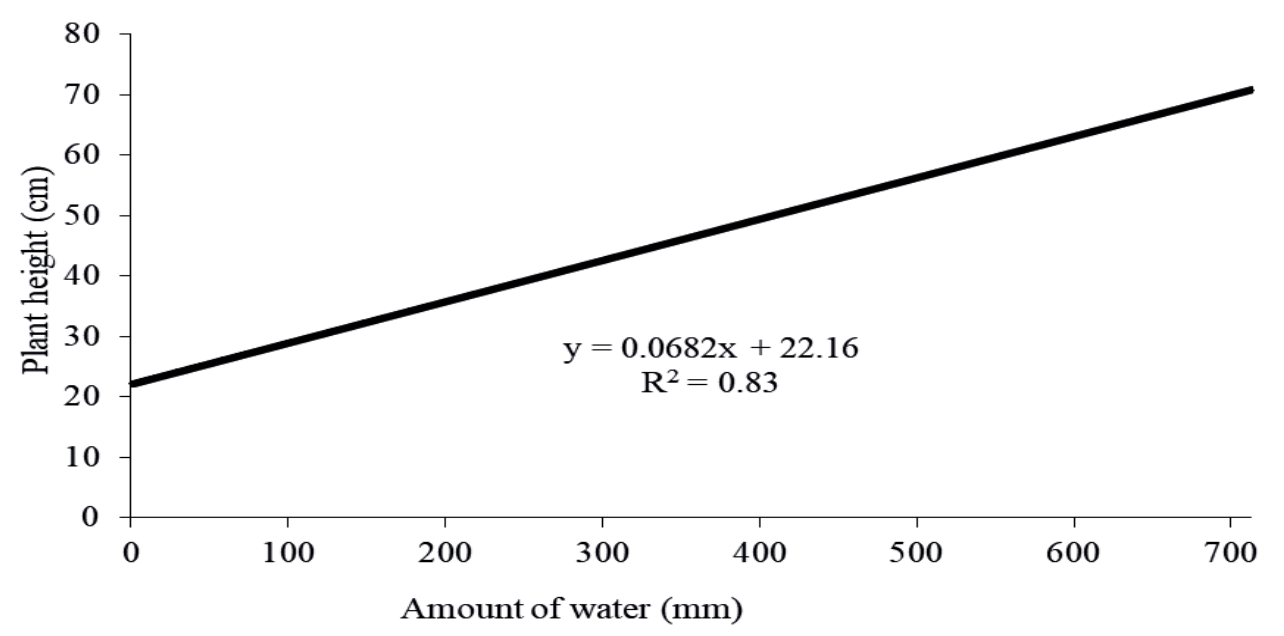


Figure 3. Relation between plant height $(\mathrm{cm})$ and dry matter $(\mathrm{DM})$ production $(\mathrm{kg} / \mathrm{ha})$.

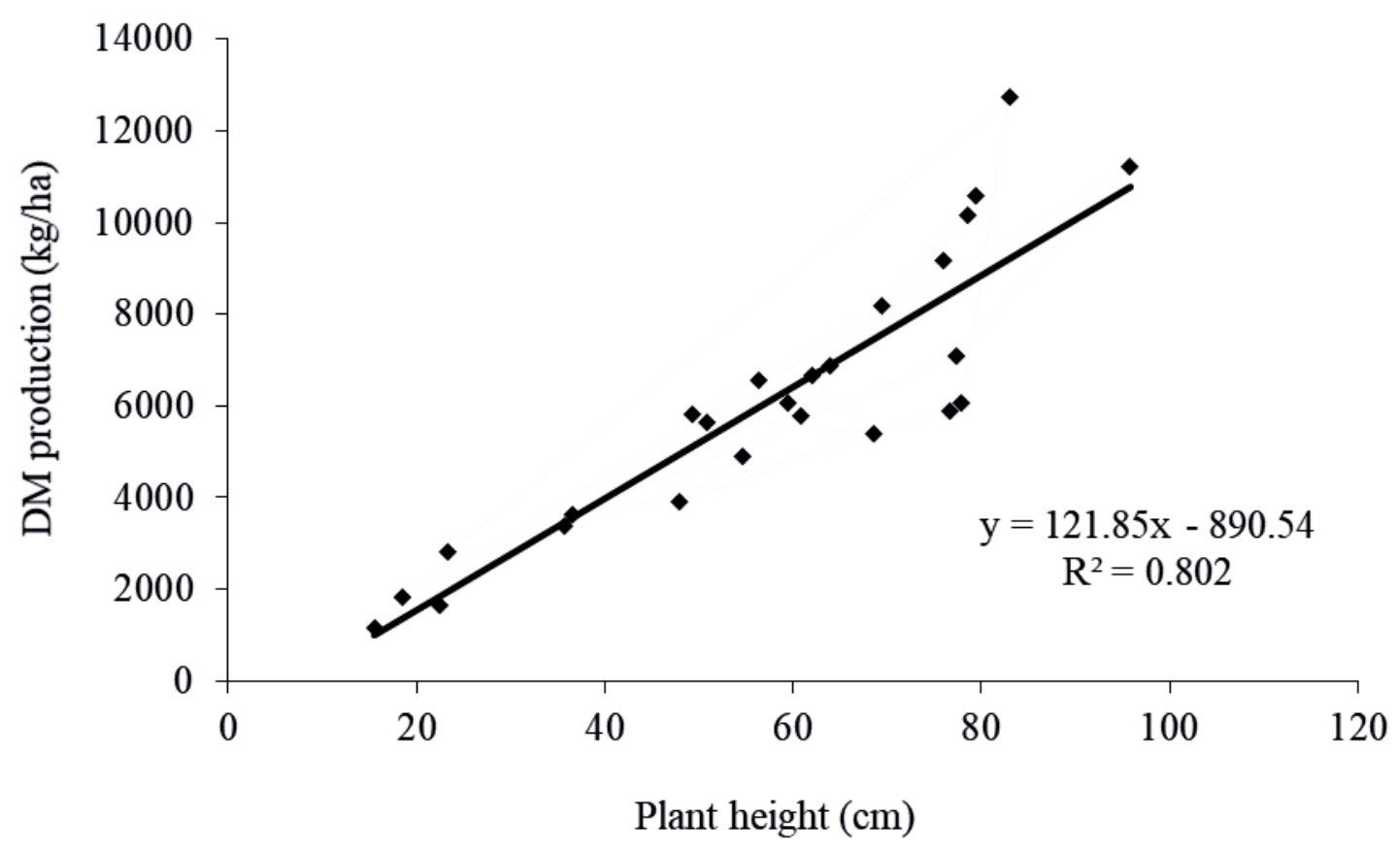

Figure 4 shows the percentage of elephant interactions between irrigation depth and nitrogen grass leaves as a function of water depth. Irrigation water was linearly and inversely $(\mathrm{P}<0.05)$ related to the percentage of leaves from May, July, and September cuts; leaf percentage decreased by $0.0936 \%, 0.0295 \%$, and $0.0122 \%$ in the three months, respectively, with every $1.0 \mathrm{~mm}$ increase in water levels (Figures 5a-c). This reduction in leaf proportion represents a decrease in the nutritive value of the forage because leaves generally have higher CP and lower NDF than stems (GOMIDE, 2001). In contrast to our results, however, a study on $B$. brizantha $\mathrm{cv}$. Marandu did not find significant fertilization on leaf elongation rate (MAGALHÃES et al., 2016).

The inverse relationship between leaf percentage and irrigation resulted in a linear reduction $(\mathrm{P}<$ 0.05 ) of the leaf/stem ratio by 0.0047 (May), 0.0020 (July), and 0.00057 (September) units per $1.0 \mathrm{~mm}$ of irrigation water (Tables 2-4). Research on tanzania guinea grass found that pre-grazing leaf mass was higher under irrigation treatment; irrigation was able to prolong the grazing period (March, April) through its positive effects on grass during September and October) (SILVA et al., 2007). 
Figure 4. Estimated leaf percentage in elephant grass $\mathrm{cv}$. Roxo as a function of water applied (mm) during irrigation. (a) May, (b) July, (c) September.

(a)

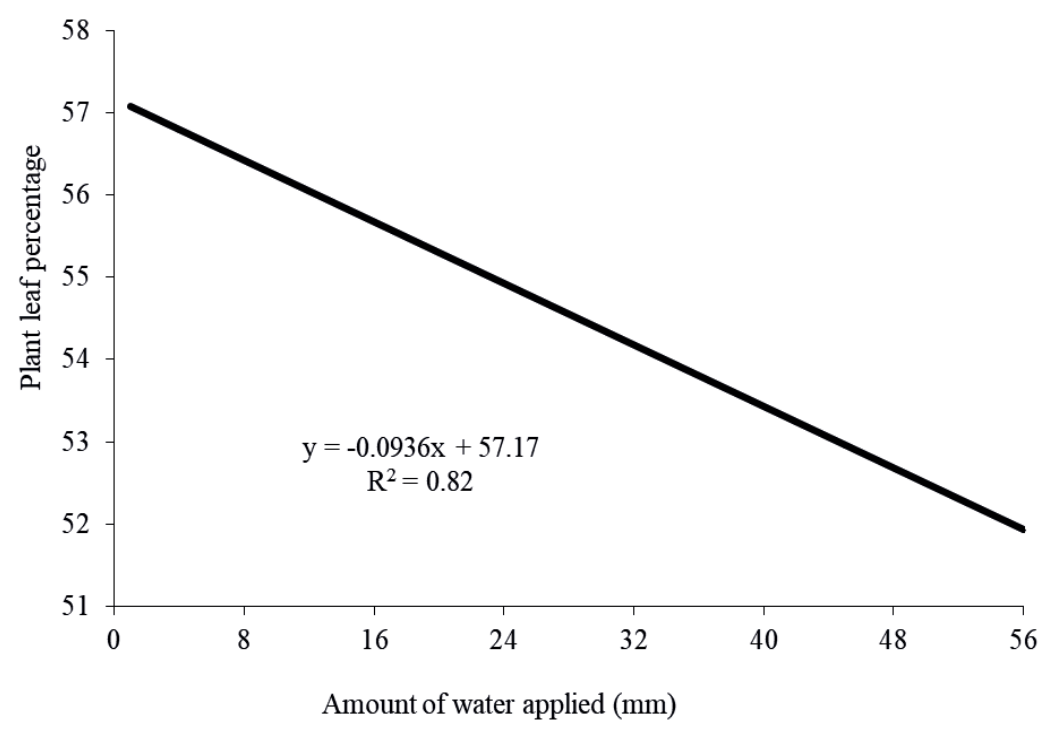

(b)

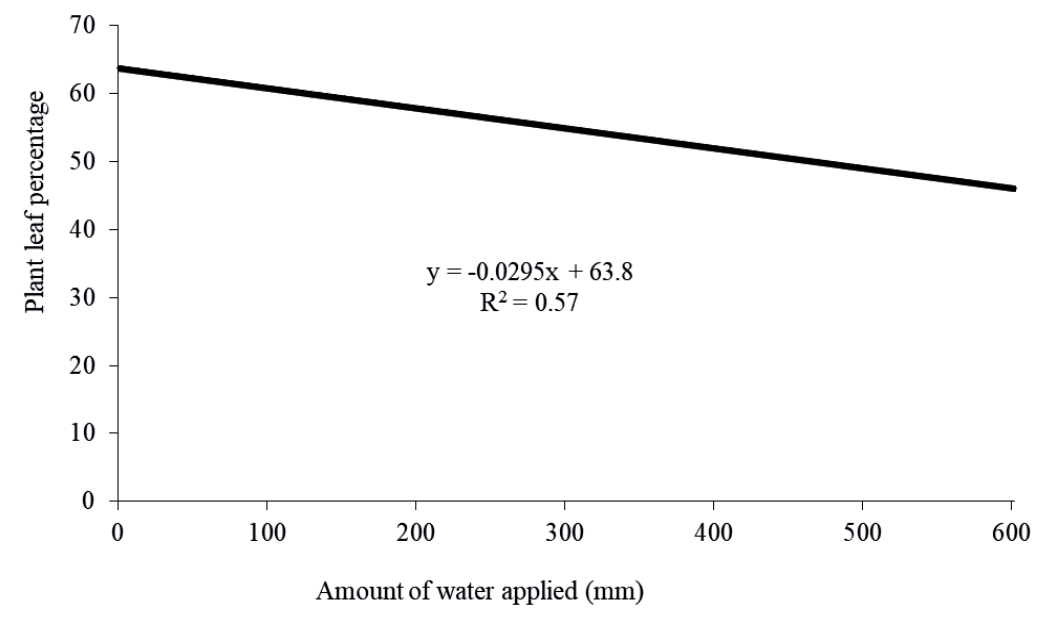

(c)

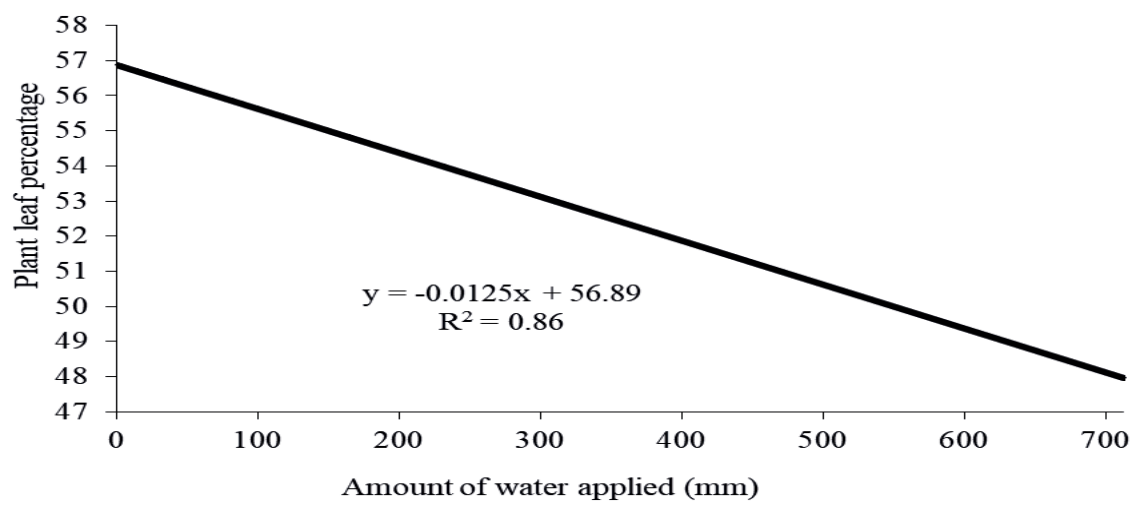


Table 2. Effect of irrigation water depth (WD, mm) on mean dry matter (DM) production ( $\mathrm{kg} / \mathrm{ha})$, height (H, $\mathrm{cm})$, and leaf percentage (L, \%) of elephant grass (Pennisetum purpureum cv. Roxo) cut in May.

\begin{tabular}{lcccccccc}
\hline \multirow{2}{*}{ Variable } & \multicolumn{3}{c}{ WD } & \multicolumn{3}{c}{ Effect } & \multicolumn{2}{c}{ CV } \\
\cline { 2 - 6 } & 1.22 & 13.74 & 26.88 & 45.12 & 56.03 & $\mathrm{~L}$ & $\mathrm{Q}$ & $\%$ \\
$\mathrm{DM}^{1}$ & 1696 & 1822 & 1955 & 2905 & 3284 & 0.0007 & $\mathrm{~ns}$ & 25.77 \\
$\mathrm{H}^{2}$ & 35.74 & 36.56 & 47.97 & 49.31 & 56.34 & 0.0007 & $\mathrm{~ns}$ & 15.77 \\
$\mathrm{~L}^{3}$ & 55.99 & 57.21 & 54.82 & 53.27 & 51.24 & 0.009 & $\mathrm{~ns}$ & 11.78 \\
\hline
\end{tabular}

${ }^{1} \hat{Y}=2958.51+60.11 X\left(R^{2}=0.91\right) ;{ }^{2} \hat{Y}=34.60+0,3725 X\left(R^{2}=0.91\right) ;{ }^{3} \hat{Y}=57.17-0.0936 X\left(R^{2}=0.82\right)$. L: linear effect, $Q$ : quadratic effect, $\mathrm{CV}$ : coefficient of variation, ns: not significant.

Table 3. Effects of irrigation water depth $(\mathrm{WD}, \mathrm{mm})$ on mean dry matter $(\mathrm{DM})$ production $(\mathrm{kg} / \mathrm{ha})$, height $(\mathrm{H}, \mathrm{cm})$, and leaf percentage (L, \%) of elephant grass cv. Roxo cut in July.

\begin{tabular}{lcccccccc}
\hline \multirow{2}{*}{ Variable } & \multicolumn{3}{c}{ WD } & \multicolumn{3}{c}{ Effect } & \multicolumn{2}{c}{ CV } \\
\cline { 2 - 6 } & 6.4 & 48.01 & 101.01 & 304.94 & 601.78 & $\mathrm{~L}$ & $\mathrm{Q}$ & $\%$ \\
$\mathrm{DM}^{1}$ & 582 & 820 & 2448 & 2694 & 3028 & 0.0000 & $\mathrm{~ns}$ & 23.65 \\
$\mathrm{H}^{2}$ & 15.55 & 22.44 & 54.64 & 68.66 & 59.44 & 0.0030 & 0.008 & 36.18 \\
$\mathrm{~L}^{3}$ & 6875 & 67.29 & 52.90 & 48.98 & 49.95 & 0.000 & $\mathrm{~ns}$ & 11.02 \\
\hline
\end{tabular}

${ }^{1} \hat{\mathrm{Y}}=2261.64+7.426 \mathrm{X}\left(\mathrm{R}^{2}=0.66\right) ;{ }^{2} \hat{\mathrm{Y}}=16.21+0.3048 \mathrm{X}-0.00039 \mathrm{X}^{2}\left(\mathrm{R}^{2}=0.91\right)$

${ }^{3} \hat{Y}=63.80-0.0295 X\left(R^{2}=0.57\right)$. L: linear effect, Q: quadratic effect, CV: coefficient of variation, ns: not significant.

Table 4. Effects of irrigation water depth $(\mathrm{WD}, \mathrm{mm})$ on mean $(\mathrm{DM})$ production $(\mathrm{kg} / \mathrm{ha})$, height $(\mathrm{H}, \mathrm{cm})$, and leaf percentage (L, \%) of elephant grass cv. Roxo cut in September.

\begin{tabular}{lcccccccc}
\hline Variable & \multicolumn{9}{c}{ WD } & \multicolumn{3}{c}{ Effect } & CV \\
\cline { 2 - 6 } & 4.57 & 127.82 & 234.92 & 497.15 & 713.11 & $\mathrm{~L}$ & $\mathrm{Q}$ & $\%$ \\
$\mathrm{DM}^{1}$ & 916 & 1405 & 2818 & 3438 & 3327.40 & 0.000 & 0.0023 & 20.21 \\
$\mathrm{H}^{2}$ & 18.47 & 23.26 & 50.83 & 61.98 & 63.89 & 0.000 & $\mathrm{~ns}$ & 17.57 \\
$\mathrm{~L}^{3}$ & 56.79 & 57.19 & 51.89 & 50.25 & 48.61 & 0.004 & $\mathrm{~ns}$ & 17.09 \\
\hline${ }^{1} \hat{\mathrm{Y}}=1427.92+19.64 \mathrm{X}-0.0170 \mathrm{X}^{2}\left(\mathrm{R}^{2}=0.95\right) ;{ }^{2} \hat{\mathrm{Y}}=22.16+0.0682 \mathrm{X}\left(\mathrm{R}^{2}=0.83\right)$ \\
${ }^{3} \hat{\mathrm{Y}}=56.89-0.01252 \times\left(\mathrm{R}^{2}=0.86\right)$. L: linear effect, Q: quadratic effect, $\mathrm{CV}$ : coefficient of variation, ns: not significant.
\end{tabular}

Throughout plant development, the leaf/stem fraction of total DM decreases progressively as stem elongation intensifies. This gradual reduction in the leaf/stem ratio occurs because plants allocate more assimilates to reproductive portions at the expense of vegetative growth (MACHADO et al., 1984; FORMOSO, 1987; BARBOSA, 2003). The relevance of the leaf/stem ratio varies according to the forage species, being lower in plants with less lignified stems (GOMIDE; GOMIDE, 2001).

\section{Conclusions}

We demonstrated that increasing irrigation water depth increases DM and plant height in elephant grass cv. Roxo, cut every 60 days. Simultaneously, however, increasing water depth reduces leaf blade percentage and the leaf/stem ratio. Overall, we recommend irrigation as a management method to increase dry-season DM production in this major forage species of southwest Mato Grosso. 


\section{References}

BARBOSA, M. A. A. F. de. Desempenho de novilhos e fluxo de tecidos em Panicum maximum Jacq. cv. Tanzânia sob diferentes ofertas de forragem. 2003. Tese (Doutorado em Zootecnia) - Universidade Federal de Viçosa, Viçosa, MG.

CARVALHO, L. A.; MARTINS, M. S.; SALDANHA, E. M. Bibliografia de Pennisetum purpureum Schum, Brasília: Embrapa, DID, 1982. 380 p.

COMISSÃO DE FERTILIDADE DO SOLO DO ESTADO DE MINAS GERAIS. Recomendações para o uso de corretivos e fertilizantes em Minas Gerais. $5^{\text {a }}$ aproximação. Viçosa: EPAMIG/UFV, 1999, 359 p.

CÓSER, A. C.; MARTINS, C. E.; DERESZ, F.; FREITAS, A. F.; PACIULLO, D. S. C.; ALENCAR, C. A. B.; VÍTOR, C. M. T. Produção de forragem e valor nutritivo do capim-elefante, irrigado durante a época seca. Pesquisa Agropecuária Brasileira, Brasília, v. 43, n. 11, p. 1625-1631, 2008.

EMPRESA MATO GROSSENSE DE PESQUISA, ASSISTÊNCIA E EXTENSÃO RURAL - EMPAER, Manual técnico de microbacias hidrográficas, $1^{\text {a }}$ aproximação 1991. Cuiabá: Editora EMPAER MT, 2000. $337 \mathrm{p}$.

FORMOSO, F. A. Crescimento e produtividade de Andropogon gayanus Kunth, Hyparrhenia rufa (Nees) Stapf e Setaria anceps (Schumm.) Stapf \& Hub. Cultivados sob dois espaçamentos e submetidos a dois intervalos de corte. 1987. Dissertação (Mestrado em Zootecnia) - Universidade Federal de Viçosa, Viçosa, MG.

GOMIDE, J. A.; GOMIDE, C. A. M. Utilização e manejo de pastagens. In: REUNIÃO ANUAL DA SOCIEDADE BRASILEIRA DE ZOTECNIA, 2001, Piracicaba. Anais... Piracicaba: SBZ, 2001. CD-ROM. Forragicultura. Semi 54.

GOMIDE, J. A.; QUEIROZ, D. S. Valor alimentício das "Brachiarias". In: SIMPÓSIO SOBRE MANEJO DA PASTAGEM. 11., Piracicaba, 1994. Anais... Piracicaba: FEALQ, 1994. p. 223-2248

GUELFI FILHO, H. Efeito da irrigação sobre a produtividade do capim-elefante (Pennisetum purpureum) variedade Napier. 1972. Dissertação (Mestrado em Agronomia) - Escola Superior de Agricultura Luiz de Queiroz, Piracicaba.

GUELFI FILHO, H. Efeito da irrigação sobre o capim colonião (Panicum maximum). Revista O Solo, Viçosa, v. 68, n. 1, p. 12-16, 1978.

LIMA, E. S.; COELHO DA SILVA, J. F.; VASQUEZ, H.
M.; ARAUJO, S. A. C.; LISTA, F. N.; COSTA, D. P. B. Produção de matéria seca, proteína bruta e relação folha/ colmo de genótipos de capim-elefante, aos 56 dias de rebrota. Revista Brasileira de Zootecnia, Viçosa, v. 36, n. 5, p. 1518-1523, 2007.

MACHADO, R. C. R.; MORENO, M. A.; ALVIM, P. T. Produtividade dos capins carimágua e colonião durante dois ciclos de crescimento. Revista Theobroma, Bahia, v. 14, n. 3, p. 229-240, 1984.

MAGALHÃES, J. A.; CARNEIRO, M. S. de. S.; ANDRADE, A. C.; RODRIGUES, B. H. N.; COSTA, N. de. L.; SANTOS, F. J. de. S.; EDVAN, R. L.; ARAÚJO NETO, R. B. de. Características morfogênicas e estruturais do capim-marandu sob irrigação e adubação. Holos, Rio Grande do Norte, v. 8, n. 1, p. 113 - 124, 2016.

RASSINI, J. B. Criação de bovinos de corte na região sudeste: irrigação de pastagens. São Carlos: EMBRAPA Pecuária Sudeste. 2003. 5 p.

RIBEIRO, E. G.; FONTES, C. A. A.; PALIERAQUI, J. G. B.; CÓSER, A. C.; MARTINS, C. E.; SILVA, R. C. Influência da irrigação, nas épocas seca e chuvosa, na produção e composição química dos capins napier e mombaça em sistema de lotação intermitente. Revista Brasileira de Zootecnia, Viçosa, v. 38, n. 8, p. 14321442, 2009.

SISTEMA DE ANÁLISES ESTATÍSTICAS E GENÉTICAS - SAEG. Versão 8.1, Viçosa: MG, 1998. 150 p. (Manual do usuário).

SILVA, C.E.; SANTOS, P. M.; COSTA, C.; MEIRELLES, P. R. de L.; SILVA, A. da S.; FACTORI, M. A. Produção e composição morfológica do capim-Tanzânia sob pastejo com e sem irrigação. Boletim Indústria Animal, Nova Odessa. v. 64, n. 4 p. 321-328, 2007.

TEIXEIRA VITOR, C. M.; FONSECA, D. M. da; CÓSER, A. C.; MARTINS, C. E.; NASCIMENTO JÚNIOR, D. do; RIBEIRO JÚNIOR, J. I. Produção de matéria seca e valor nutritivo de pastagem de capimelefante sob irrigação e adubação nitrogenada. Revista Brasileira de Zootecnia, Viçosa, v. 38, n. 3, p. 435-442, 2009

VANZELA, L. S.; ANDRADE, M. C. N. Manejo da irrigação via solo. UNESP: Ilha Solteira, 2007. 9 p. (Apostila).

VAN GENUCHTEN, M.T. A closed-form equation for predicting the hydraulic conductivity of unsatured soil. Soil Science Society of America Journal, Madison, v. 44, p.892-898, 1980. 
